\title{
Pengaruh Profesionalisme Dan Time Budget Pressure Pada Kinerja Auditor Dengan Motivasi Auditor Sebagai Variabel Pemoderasi
}

\author{
Made Irna Wikanadi ${ }^{1}$ \\ Ketut Alit Suardana ${ }^{2}$ \\ ${ }^{1,2}$ Fakultas Ekonomi dan Bisnis Universitas Udayana (Unud), Bali, Indonesia \\ e-mail: irnawikanadi@gmail.com
}

\begin{abstract}
ABSTRAK
Penelitian ini dilakukan di Perwakilan BPKP Provinsi Bali. Sampel dalam penelitian ini adalah seluruh auditor dengan jumlah auditor secara keseluruhan sebanyak 74 orang. Banyaknya sampel penelitian yang digunakan adalah 51 responden, dengan metode sampling jenuh. Metode pengumpulan data yang digunakan adalah menggunakan kuesioner yang disebarkan langsung kepada auditor yang bekerja di Perwakilan BPKP Provinsi Bali. Teknik analisis data yang digunakan adalah analisis regresi linear berganda dan Moderated Regression Analysis (MRA). Berdasarkan hasil analisis regresi linear berganda ditemukan bahwa profesionalisme berpengaruh positif pada kinerja auditor dan time budget pressure berpengaruh negatif pada kinerja auditor. Berdasarkan hasil regresi moderasi bahwa motivasi auditor meningkatkan pengaruh profesionalisme dan time budget pressure pada kinerja auditor.
\end{abstract}

Kata Kunci: profesionalisme, time budget pressure, motivasi auditor, kinerja auditor

\begin{abstract}
This research was conducted at the BPKP Representative of Bali Province. The sample in this study were all auditors with a total auditor number of 74 people. The number of research samples used was 51 respondents, with a saturated sampling method. The data collection method used was using a questionnaire that was distributed directly to the auditors who worked in BPKP Representatives of Bali Province. The data analysis technique used is multiple linear regression analysis and Moderated Regression Analysis (MRA). Based on the results of multiple linear regression analysis found that professionalism has a positive effect on auditor performance and time budget pressure has a negative effect on auditor performance. Based on the regression moderation results that auditor motivation increases the influence of professionalism and time budget pressure on auditor performance.

Keywords: professionalism, time budget pressure, auditor motivation, auditor performance
\end{abstract}

\section{PENDAHULUAN}

Pengelolaan keuangan negara yang dilakukan dengan baik akan berdampak pada suksesnya pembangunan nasional. Demi tercapainya hal tersebut, pengawasan terhadap pengelolaan keuangan negara harus terbebas dari penyimpangan dan dilaksanakan sesuai dengan tujuan yang direncanakan.Siklus manajemen 
Made Irna Wikanadi dan Ketut Alit Suardana. Pengaruh...

pemerintahan menunjukkan bahwa Badan Pengawasan Keuangan dan Pembangunan (BPKP) merupakan Lembaga Pemerintahan yang mempunyai tugas pemerintahan di bidang pengawasan dan pembangunan sebagaimana disebutkan dalam Peraturan Presiden Nomor 192 Tahun 2014menyebutkan bahwa BPKP mempunyai tugas melaksanakan urusan pemerintahan di bidang pengawasan keuangan negara atau daerah dan pembangunan nasional. Salah satu tugas pokok dan fungsi melakukan pengawasanintern yang dilaksanakan oleh BPKP yaitu audit. Standar audit yang diterapkan selain memberikan jaminan kualitas audit juga untuk menghindari adanya tuntutan dan ketidakpuasan hasil audit yang dilakukan BPKP.

Menurut Peraturan Presiden Nomor 192 Tahun 2014menyebutkan BPKP menyelenggarakan fungsiperumusan kebijakan nasional pengawasan intern terhadap akuntabilitas keuangan negara/daerah dan pembangunan nasional meliputi kegiatan yang bersifat lintas sektoral, kegiatan kebendaharaan umum negara berdasarkan penetapan oleh Menteri Keuangan selaku Bendahara Umum Negara, dan kegiatan lain berdasarkan penugasan dari Presiden. Upaya dalam meningkatkan kinerja untuk setiap profesi menjadi tema penting bagi organisasi profesi dalam menjaga keberadaan dan kepercayaan masyarakat. Banyaknya kasus penyimpangan keuangan yang berada di Bali menyebabkan peran dari BPKP ini sangat dipertanyakan. Mengapa lembaga pengawasan ini belum mampu melaksanakan fungsi dengan baik sehingga penyimpangan itu bisa terjadi, padahal disisi lain pengawasan, pemeriksaan, pembina, dan pengelolaan keuangan daerah adalah tugas pokok dari BPKP. 
Contoh kasus yang terjadi pada Perwakilan BPKP Provinsi Bali, dimana terdapat hasil audit yang dipertanyakan hasilnya oleh stakeholders. Hasil audit penghitungan kerugian keuangan negara atas kasus tindak pidana korupsi pada Institit Hindu Dharma Negeri (IHDN) Denpasar tahun 2012, dipertanyakan oleh Penasehat Hukum dan tersangka saat persidangan, karena hasil audit BPKP berbeda dengan hasil audit yang dilakukan oleh Badan Pemeriksa Keuangan, selain itu ahli dari BPKP yang dihadirkan di persidangan oleh Jaksa Penuntut Umum (JPU) dinilai bersifat tendensius dalam memberikan keterangan sehingga diragukan kualitas hasil audit dan kompetensi auditor (Sukendro, 2015).

Auditor BPKP sebagai auditor internal pemerintah harus meningkatkan kinerjanya baik untuk kebutuhan masa kini maupun antisipasi kebutuhan masa yang akan datang (Sumardi dan Hardiningsih, 2002). Tingginya tingkat kemampuan auditor sangat mempengaruhikinerja audit yang menunjukkan bahwa bila auditor memiliki perilaku profesional yang lebih besar, dia akan efektif dalam mencerminkan kinerja auditor yang lebih tinggi, begitupun sebaliknya (Baotham, 2007).Upaya meningkatkan kinerjanya, auditor dihadapkan pada berbagai tantangan dalam mewujudkan transparasi dan akuntabilitasnya. Berdasarkan penjelasan tersebut diharapkan auditor dapat melaksanakan audit sesuai dengan yang direncanakan dan sesuai dengan standar audit yang telah ada.

Menurut Kalbers dan Fogarty (1995) menyatakan bahwa kinerja merupakan hasil kerja yang dicapai seseorang dalam melaksanakan tugas sesuai dengan tanggung jawab yang diberikan. Kinerja merupakan hasil atau tingkat keberhasilan seseorang secara keseluruhan selama periode tertentu dalam 
melaksanakan tugas dibandingkan dengan berbagai kemungkinan, seperti standar hasil kerja, target sasaran atau kriteria yang telah ditentukan terlebih dahulu telah disepakati bersama. Kinerja kerap digunakan untuk menunjukan prestasi individu maupun kelompok individu (Marion, 2009). Kinerja auditor merupakan ukuran hasil yang sesuai dengan penugasan dari auditee dan menjadi tanggungjawab pada auditor serta dapat dijadikan ukuran prestasi untuk menilai apakah suatu pekerjaan yang dilaksanakan sudah baik atau sebaliknya. Aspek yang penting dalam peningkatan kinerja auditor adalah keberhasilan suatu instansi atau perusahaan dapat tercapai dengan upaya dan kualitas sumber yang dimilikinya. Begitu juga dengan BPKP, keberhasilan BPKP dalam mengembangkan misi pemeriksaan sangat tergantung dari upaya dan kualitas para auditornya.

Faktor yang dapat mempengaruhi kinerja auditor adalah profesionalisme yang dapat diartikan sebagai sikap profesional sering dinyatakan dalam literatur, profesionalisme berarti bahwa orang bekerja secara professional (Hudiwinarsih, 2010). Profesionalisme meliputi kemampuan penguasaan baik secara teknis, maupun secara teoritis bidang keilmuan dan keterampilan yang berhubungan dengan tugasnya sebagai pemeriksa (Asri et al., 2014). Menjaga kepercayaan menjadi kewajiban auditor dihadapan klien maupun pihak ketiga dengan senantiasa meningkatkan keahlian profesionalnya (Mu'azu dan Siti, 2013). Sebagai seorang auditor harus mampu menerapkan profesionalisme, kemampuan danpengetahuan yang dimiliki dalam melaksanakan penugasan audit untuk menghasilkan audit yang berkualitas (Marganingsih dan Martani, 2002). 
Selain itu faktor yang mempengaruhi kinerja auditor adalah tekanan anggaran waktu (time budget pressure) yang merupakan suatu kondisidimana auditor memiliki waktu yang singkat dalam melaksanakan program audit (Indrajaya dkk., 2017). Tekanan waktu sering dipandang dapat menurunkan kinerja, namun apabila alokasi waktu dilakukan dengan tepat justru berfungsi sebagai mekanisme kontrol dan suatu indikator keberhasilan bagi kinerja auditor (Cook dan Kelly, 1991). Menurut Lautania(2011)dalam melaksanakan proses audit, auditor dituntut untuk dapat melaksanakan tugasnya dengan melakukan efisiensi dalam biaya waktu. Tuntutan laporan yang berkualitas dengan waktu yang terbatas merupakan tekanan tersendiri bagi auditor. Menurut Ahituv dan Igbaria(1998) menyatakan bahwa ini berpengaruh pada kualitas kerja maupun kinerja auditor tersebut yang pada akhirnya dapat mempengaruhi laporan audit yang dihasilkan. Tekanan anggaran waktu bisa menimbulkan implikasi yang kritis bagi etika, kualitas audit, dan kesejahteraan auditor (Liyanarachchi dan McNamara, 2007). Dampak negatif yang ditimbulkan dari time budget pressure adalah auditor sengaja untuk menghilangkan beberapa tahapan audit karena alasan keterbatasan waktu, sehingga akan menurunkan kualitas audit.Willett dan Page (1996) menemukan bahwa penyebab terbesar menurunnya kinerja auditor dipengaruhi oleh faktor tekanan anggaran waktu.Menurut DeZoort dan Lord (1997) menyebutkan bahwa saat menghadapi tekanan anggaran waktu, auditor akan memberikan respon dengan dua cara yaitu dengan tipe fungsional dan tipe disfungsional. 
Faktor yang juga dapat mempengaruhi kinerja auditor yaitu motivasi auditor.Motivasi adalah suatu dorongan yang timbul dari dalam diri manusia untuk melakukan suatu tindakan. Meskipun terdapat aktivitas manusia yang dilakukan tanpa motivasi, tetapi hampir seluruh perilaku yang dilakukan dengan sadar memiliki motivasi atau sebab. Kebutuhan menimbulkan potensi yang dimodifikasi oleh lingkungan seseorang dan menimbulkan keinginan tertentu. Atas pertimbangan seseorang terhadap situasinya secara menyeluruh, orang tersebut termotivasi untuk melakukan tindakan yang memenuhi kebutuhan mereka. Sikap mental seseorang yang pro dan positif terhadap situasi kerja itulah yang memperkuat motivasi kerjanya untuk mencapai kinerja maksimal.Salah satu motivasi auditor untuk memberikan kinerja yang maksimal adalah sikap profesionalnya.Time budget pressure juga merupakan konsistensi adanya motivasi auditor dari wujud keterikatan seorang auditor untuk dapat menyelesaikan pekerjaannya tepat pada waktu yang telah dianggarkan.

Penelitian yang dilakukan oleh Cahyani dkk., (2015), Ramadika dkk., (2014), serta Handayani dan Yusrawati (2012) menunjukkan bahwa profesionalisme berpengaruh positif terhadap kinerja auditor.Berbeda dengan penelitian Haris (2015) yang menyebutkan profesionalisme tidak berpengaruh pada kinerja auditor. Penelitian Putridan Suputra (2013) menjelaskan bahwa jika auditor tidak mampu dengan tepat waktu melaporkan laporan auditnya maka menunjukkan rendahnya profesionalisme auditor.Penelitian Hutabarat(2012) serta Prasita dan Adi (2007) yang menyatakan bahwa time budget pressure berpengaruh negatif terhadap kinerja auditor. Berbeda dengan penelitian Arisinta 
(2013) menyebutkan bahwa time budget pressure berpengaruh positif terhadap kinerja auditor. Hasil penelitian pendahulu juga dilakukan Christiyanto (2011) dan Sujana (2012) yang menunjukkan bahwa motivasi berpengaruh positif pada kinerja auditor.

Auditor dengan sikap profesional yang tinggi akan memberi pengaruh pada kinerjanya sehingga auditor tersebut dapat bekerja dengan lebih baik dan mampu memberikan hasil audit yang dapat dipercaya oleh pihak-pihak yang berkepentingan baik pihak internal maupun pihak eksternal perusahaan.Hal tersebut sesuai dengan teori atribusi yang menyatakan bahwa individu akan berusaha menganalisis mengapa peristiwa muncul dan hasil dari analisis tersebut akan mempengaruhi perilaku mereka di masa mendatang (Riantiningtyas, 2009). Semakin tinggi perilaku profesional yang dimiliki auditor, maka akan semakin membentuk karakteristik personal auditor tersebut. Karakteristik personal tersebut merupakan faktor internal yang mendorong seseorang untuk melakukan suatu aktivitas yang kemudian akan meningkatkan kinerjanya.

Hasil penelitian yang dilakukan oleh Prabhawa (2014) menyatakan auditor yang bersikap profesional lebih dipercaya sebagai seorang auditor yang memiliki kompetensi yang baik sehingga hasil audit yang diberikan akan semakin baik. Pernyataan tersebut juga didukung oleh hasil penelitian dari Kusnadi (2015) yang menyatakan bahwa profesionalisme berpengaruh positif terhadap kinerja auditor.Berdasarkan pemamparan diatas dapat diajukan rumusan hipotesis sebagai berikut.

$\mathrm{H}_{1}$ : Profesionalisme berpengaruh positif pada kinerja auditor 
Anggaran waktu memaksa auditor untuk cepat menyelesaikan tugasnya sesuai dengan anggaran waktu yang telah diberikan. Menurut Khadilah dkk., (2015) menyatakan bahwa penurunan kualitas audit telah ditemukan akibat ketatnya anggaran waktu. Teori atribusi menyatakan bahwa atribusi eksternal dapat mempengaruhi perilaku seseorang. Hal ini memberikan penjelasan bahwa faktor eksternal seperti tekanan anggaran waktu auditor bisa saja mengubah perilaku auditor. Perubahan tersebut dapat berupa perubahan yang fungsional maupun disfungsional.Alderman dan Deitrick (1982) menyatakan bahwa tekanan anggaran waktu sebagai faktor utama yang memengaruhi tingkatan dari penurunan kualitas audit. Auditor diberikan anggaran waktu sebagai dasar untuk melakukan prosedur audit agar lebih efektif dan efisien dalam menyelesaikan tugasnya.Anggaran waktu yang diberikan justru bersifat memaksa auditor agar cepat menyelesaikan tugasnya. Mcdaniel (1990) menemukan bahwa tekanan anggaran waktu menyebabkan suatu penurunan efektifitas dan efisiensi kegiatan pengauditan. Pada penelitian Coram dan Woodliff (2003) menemukan alasan utama melakukan tindakan penurunan kualitas audit adalah karena terdapat tekanan anggaran waktu.

Menurut penelitianPrasita dan Adi (2007), Hutabarat (2012), serta Ningsih (2013) yang menyatakan bahwa terdapat pengaruh yang negatif antara time budget pressure yang diberikan terhadap kinerja auditor. Karena dengan adanya tekanan anggaran waktu yang tinggi dapat menurunkan kualitas dari kinerja seorang auditor. Berdasarkan pemamparan diatas dapat diajukan rumusan hipotesis sebagai berikut. 
$\mathrm{H}_{2}$ : Time budget pressure berpengaruh negatif pada kinerja auditor.

Menurut Trisnaningsih (2007) menyatakan bahwa profesionalisme pada dasarnya merupakan hal yang berintikan loyalitas, tekad dan harapan individu pada profesinya. Pencapaian dengan tingkat keberhasilan yang tinggi akan memberikan kepuasan kerja bagi seorang individu dalam menyelesaikan tugasnya.Atribusi internal dan eksternal dinyatakan mempengaruhi sikap dan kepuasaan individu terhadap kerja (Kurnia dkk., 2014). Berdasarkan teori atribusi, faktor internal motivasi dalam diri auditor dan faktor eksternal dari luar diri auditor membawa pengaruh positif atau peningkatan terhadap profesionalisme yang lebih baik sehingga meningkatkan kinerja auditor dalam melaporkan hasil auditnya.

Seorang auditor dapat bekerja sama dan berkinerja dengan baik, maka seorang auditor harus mempunyai profesionalisme dalam menerapkan suatu profesi yang dimiliki dan menjadi suatu motivasi kerja untuk meningkatkan hasil kinerja auditor yang diharapkan (Siregar, 2014). Adanya keyakinanpada profesi dengan menerapkan profesionalisme dapat memberikan motivasi bagi auditor untuk menciptakan hasil pekerjaan serta pertimbangan yang dapat dipertanggungjawabkan. Adapun motivasi itu sendiri dapatmeningkatkan profesionalisme dalam menerapkan suatu profesi yang dimiliki seseorang pada kemauan individu untuk menggunakan usaha yang tinggi dalam upaya mencapai tujuan-tujuan perusahaandan memenuhi kebutuhan-kebutuhannya. Berdasarkan pemamparan diatas dapat diajukan rumusan hipotesis sebagai berikut.

$\mathrm{H}_{3}$ : Motivasi auditor meningkatkan pengaruh profesionalisme pada kinerjaAuditor 
Auditor akan merasakan adanya tekanan waktu pada saat melaksanakan program audit akibat ketatnya anggaran waktu audit yangdialokasikan atau terjadi ketidakseimbangan antara anggaran waktu audit yang tersedia dengan kebutuhan waktu nyata untuk menyelesaikan keseluruhan program audit (Kelley dan Seiler, 1982). Menurut Kurnia dkk., (2014) atibusi eksternal dinyatakan dapat mempengaruhi evaluasi kinerja individu. Berdasarkan hal tersebut diperoleh penjelasan bahwa atribusi eksternal tekanan anggaran waktu audit dapat mempengaruhi kinerja individu. Atribusi ekstenal ini mempengaruhi perilaku auditor melalui tekanan yang dirasakan auditor sebagai akibat dari susunan anggaran waktu audit yang dialami ketika melaksanakan penugasan audit. Adapun pengaruh positif yang dapat ditimbulkan dari adanya time budget pressure antara lain adanya motivasi yang tinggi dari seorang auditor untuk dapat menyelesaikan pekerjaannya tepat pada waktunya. Sementara itu pengaruh negatif dari adanya time budget pressure adalah akan menimbulkan sikap dalam tindakan profesional yang dapat mengurangi kualitas audit.

Menurut Rustiarini (2013) menyatakan bahwa adanya respon yang positif dalam menghadapi tekanan waktu yang tinggi, sehingga digunakan sebagai alat untuk memotivasi auditor dalam meningkatkan kualitas pekerjaannya. Dengan adanya time budget pressure ini dapat membuat motivasi auditor semakin besar dan mengakibatkan kualitas kinerja auditor semakin berkurang, karena semakin tingginya tekanan anggaran waktu yang diberikan perusahaan maka semakin rendah pula kualitas kinerja auditor.Berdasarkan pemaparan diatas maka dapat diajukan rumusan hipotesis sebagai berikut. 
$\mathrm{H}_{4}$ : Motivasi auditor meningkatkan pengaruh time budget pressure pada kinerja auditor

\section{METODE PENELITIAN}

Penelitian ini dilakukan di Kantor Perwakilan BPKP (Badan Pengawasan Keuangan dan Pembangunan) Provinsi Bali yang beralamat di Jl. Tantular, Panjer, Denpasar Selatan, Kota Denpasar, Bali. Lokasi tersebut dipilih dengan alasan keterjangkauan lokasi penelitian baik dari segi tenaga, dana maupun dari segi efisiensi waktu.Adapun alasan lain yang tidak kalah penting karena Perwakilan BPKP Provinsi Bali merupakan instansi vertikal BPKP yang mempunyai tugas pokok melaksanakan pengawasan (audit) intern terhadap akuntabilitas keuangan negara dan atau daerah. Berdasarkan pertimbangan tersebut, Perwakilan BPKP Provinsi Bali diperkirakan dapat mewakili masalah pokok dalam penelitian ini.

Terdapat tiga variabel dalam penelitian ini yaitu variabel-variabel yang dapat diidentifikasi dalam penelitian ini antara lain satu variabel terikat, dua variabel bebas dan satu variabel pemoderasi. Variabel dependen/terikat dalam penelitian ini adalah Kinerja Auditor. Variabel independent/bebas dalam penelitian ini adalah Profesionalisme dan Time Budget Pressure. Variabel pemoderasi dalam penelitian ini adalah Motivasi Auditor.

Populasi yang digunakan dalam penelitian ini adalah Pejabat Fungsional Auditor (PFA) Perwakilan BPKP Provinsi Bali yang berjumlah 74 orang di tahun 2018. Sampel penelitian yang diambil berdasarkan dari populasi penelitian adalah 74orang responden dalam pengisian kuesioner. 
Analisis regresi linear berganda (multiple linear regression) digunakan untuk menguji hipotesis yang ada yaitu untuk melihat pengaruh profesionalisme dan time budget pressure pada kinerja auditor. Model persamaan analisis regresi linear berganda ditunjukkan oleh persamaan regresi berikut:

$\mathrm{Y}=\alpha+\beta_{1} \mathrm{X}_{1}+\beta_{2} \mathrm{X}_{2}+\mathrm{e}$

Keterangan:

$\mathrm{Y} \quad=$ Kinerja auditor

$\alpha \quad=$ Konstanta

$\beta_{1} \beta_{2}=$ Koefisien regresi untuk masing-masing variabel independen

$\mathrm{X}_{1} \quad=$ Profesionalisme

$\mathrm{X}_{2} \quad=$ Time budet pressure

$\mathrm{e} \quad=$ Error

Model analisis data dan uji hipotesis dalam penelitian ini adalah model analisis regresi moderasi Moderated Regression Analysis (MRA) dengan rumus persamaan sebagai berikut:

$Y=\alpha+\beta_{1} X_{1}+\beta_{2} X_{2}+\beta_{3} M+\beta_{4} X_{1} \cdot M+\beta_{5} X_{2} \cdot M+e$

Keterangan:

$\begin{array}{ll}\mathrm{Y} & =\text { Kinerja auditor } \\ \alpha & =\text { Konstanta } \\ \beta_{1} \beta_{2} \beta_{3} \beta_{4} \beta_{5} & =\text { Koefisien regresi untuk masing-masing variabel independen } \\ \mathrm{X}_{1} & =\text { Profesionalisme } \\ \mathrm{X}_{2} & =\text { Time budet pressure } \\ \mathrm{M} & =\text { Motivasi auditor } \\ \mathrm{X}_{1} \mathrm{M} & =\text { Interaksi antara Profesionalisme dengan Motivasi auditor } \\ \mathrm{X}_{2} \mathrm{M} & =\text { Interaksi antara Time budet pressure dengan Motivasi auditor } \\ \mathrm{e} & =\text { Error }\end{array}$




\section{HASIL DAN PEMBAHASAN}

Responden yang berpartisipasi dalam pengisian kuesioner adalah sebanyak 51 orang. Komposisi responden berdasarkan jenis kelamin dapat dilihat pada Tabel 1 berikut.

Tabel 1.

Jumlah Responden Berdasarkan Jenis Kelamin

\begin{tabular}{lllc}
\hline \multirow{2}{*}{ No. } & \multirow{2}{*}{ Jenis Kelamin } & Orang & Jumlah \\
& & 33 & Persen \\
\hline 1 & Laki-laki & 18 & 64,71 \\
2 & Perempuan & 51 & 35,29 \\
& Total & & 100,00 \\
\hline \multicolumn{2}{l}{ Sumber $:$ Data diolah, 2018} &
\end{tabular}

Tabel 1 menunjukkan proporsi responden yang berjenis kelamin laki-laki dan perempuan. Pada Tabel 4.2 di atas diketahui bahwa dari 51 responden terdiri dari laki-laki sebanyak 33 orang (64,71 persen) dan perempuan sebanyak 18 orang (35,29 persen). Hal ini menunjukkan responden pada penelitian ini lebih banyak berjenis kelamin laki-laki dibandingkan perempuan.

Komposisi responden berdasarkan umur dapat dilihat pada Tabel 2 berikut.

Tabel 2.

Jumlah Responden Berdasarkan Umur

\begin{tabular}{cccc}
\hline No. & $\begin{array}{c}\text { Umur } \\
\text { (Tahun) }\end{array}$ & Orang & Jumlah \\
\hline 1 & $26-30$ & 16 & Persen \\
2 & $31-40$ & 15 & 31,37 \\
3 & $41-45$ & 10 & 29,41 \\
4 & $>45$ & 10 & 19,61 \\
& Total & 51 & 100,00 \\
\hline
\end{tabular}

Sumber:Data diolah, 2018

Tabel 2 menunjukkan proporsi responden yang berumur 26-30 tahun, 3140 tahun, 41-45 tahun, dan $>45$ tahun. Pada Tabel 4.3 di atas diketahui bahwa dari 51 responden terdiri dari umur 26-30 tahun sebanyak 16 orang $(31,37$ persen), umur $31-40$ tahun sebanyak 15 orang (29,41 persen), umur $41-45$ tahun 
sebanyak 10 orang $(19,61$ persen), dan umur $>45$ tahun sebanyak 4 orang $(19,61$ persen).

Komposisi responden berdasarkan tingkat pendidikan dapat dilihat pada Tabel 3 berikut.

Tabel 3. Jumlah Responden Berdasarkan TingkatPendidikan

\begin{tabular}{cccc}
\hline No. & Tingkat Pendidikan & Orang & Jumlah \\
\hline 1 & DIII & 9 & Persen \\
2 & DIV & 4 & 17,65 \\
3 & S1 & 36 & 7,84 \\
4 & S2 & 2 & 70,59 \\
& Total & 51 & 100,00 \\
\hline
\end{tabular}

Sumber:Data diolah, 2018

Tabel 3 menunjukkan proporsi responden dengan tingkat pendidikan DIII, DIV, S1, dan S2. Pada Tabel 4.4 di atas diketahui bahwa dari 51 responden terdiri dari responden dengan pendidikan DIII sebanyak 9 orang (17,65 persen), DIV sebanyak 4 orang (7,84 persen), S1 sebanyak 36 orang (70,59 persen), dan S2 sebanyak 2 orang (3,92 persen).

Komposisi responden berdasarkan masa kerja dapat dilihat pada Tabel 4.2 berikut.

Tabel 4.

Jumlah Responden Berdasarkan Masa Kerja

\begin{tabular}{cccc}
\hline No. & $\begin{array}{c}\text { Masa Kerja } \\
\text { (Tahun) }\end{array}$ & Orang & Jumlah \\
\hline 1 & $<5$ & 9 & Persen \\
2 & $5-10$ & 24 & 47,65 \\
3 & $11-15$ & 10 & 19,06 \\
4 & $16-20$ & 8 & 15,68 \\
& Total & 51 & 100,00 \\
\hline
\end{tabular}

Sumber: Data diolah, 2018

Tabel 4 menunjukkan proporsi responden yang memiliki masa kerja $<5$ tahun, 5-10 tahun, 11-15 tahun, dan 16-20 tahun. Pada Tabel 4.5 di atas diketahui bahwa dari 51 responden terdiri dari responden yang memiliki masa 
kerja $<5$ tahun sebanyak 9 orang (17,65 persen), masa kerja 5-10 tahun sebanyak 24 orang (47,06 persen), masa kerja 11-15 tahun sebanyak 10 orang $(19,61$ persen), dan masa kerja 16-20 tahun sebanyak 8 orang (15,68 persen).

Statistik deskriptif memberikan gambaran mengenai karakteristik variabel penelitian yang terdiri atas jumlah pengamatan, nilai minimum, nilai maksimum, nilai mean, dan standar deviasi. Adapun hasil dari statidtik deskriptif dapat ditunjukkan pada Tabel 5 berikut.

\section{Tabel 5.}

Hasil Statistik Deskriptif

\begin{tabular}{lccccc}
\hline & N & Minimum & Maximum & Mean & Std. Deviation \\
\hline Kinerja Auditor & 51 & 16 & 32 & 24,90 & 3,910 \\
Profesionalisme & 51 & 20 & 40 & 32,18 & 5,915 \\
Time Budget Pressure & 51 & 16 & 28 & 21,63 & 3,504 \\
Motivasi Auditor & 51 & 19 & 32 & 27,80 & 3,945 \\
\hline
\end{tabular}

Sumber:Data diolah, 2018

Tabel 5 menunjukkan bahwavariabel kinerja auditor (Y) yang diukur dengan 8 item pernyataan memiliki standar deviasi 3,910. Berdasarkan hasil uji statistik deskriptif nilai minimum kinerja auditor adalah sebesar 16, nilai maksimum sebesar 32 dan mean sebesar 24,90 yang mendekati nilai maksimum artinya auditor memiliki kinerja yang baik untuk melaksanakan audit.

Variabel profesionalisme $\left(\mathrm{X}_{1}\right)$ yang diukur dengan 10 item pernyataan memiliki standar deviasi 5,915. Berdasarkan hasil uji statistik deskriptif nilai minimum profesionalisme adalah sebesar 20, nilai maksimum sebesar 40 dan mean sebasar 32,18 yang mendekati nilai maksimum artinya hasil jawaban dari responden dapat dikatakan sudah bekerja secara profesional. Namun, masih perlu adanya peningkatan dalam pencarian ilmu yang berkaitan dengan profesinya untuk menjadi auditor yang berkualitas. Pendapat diatas dapat dibuktikan 
berdasarkan hasil rata-rata jawaban responden yang terendah pada pernyataan 7 sebesar 3,12 dan pernyataan 8sebesar 3,06 dari hasil jawaban responden.

Variabel time budget pressure $\left(\mathrm{X}_{2}\right)$ yang diukur dengan 7 item pernyataan memiliki standar deviasi 3,504. Berdasarkan hasil uji statistik deskriptif nilai minimum time budget pressure adalah sebesar 16,nilai maksimum sebesar 28 dan mean sebesar 21,63 yang mendekati nilai minimum artinya hasil jawaban dari responden dapat dikatakan masih terjadi tekanan yang dihadapi pada perencanaan anggaran waktu yang terlalu ketat sehingga penugasan audit kurang mampu memenuhi target yang telah ditentukan. Hal ini menyebabkan efisiensi dalam pekerjaan proses audit sangat ditekan. Pendapat diatas dapat dibuktikan berdasarkan hasil rata-rata jawaban responden yang terendah pada pernyataan 1 sebesar 3,06, pernyataan 5 sebesar 3,00 dan pernyataan 7 sebesar 3,06 dari hasil jawaban responden.

Variabel motivasi auditor (M) yang diukur dengan 8 item pernyataan memiliki standar deviasi 3,945. Berdasarkan hasil uji statistik deskriptif nilai minimum motivasi auditor adalah sebesar 19, nilai maksimum sebesar 32 dan mean sebesar 27,80 yang mendekati nilai maksimum artinya hasil jawaban dari responden dapat dikatakan bahwa auditor sudah diberikan kesempatan untuk mengembangkan karier dengan baik serta dengan adanya tekanan waktu yang diberikan membuat auditor termotivasi untuk bekerja dengan cepat. Namun, masih perlu adanya kelengkapan peralatan bekerja yang memadai serta perlu diciptakan lingkungan kerja yang menyenangkan. Selain itu, kurangnya pemberian reward atas tugas yang diselesaikan sehingga auditor merasa kurang 
adanya penghargaan atas apa yang telah dicapai. Pendapat diatas dapat dibuktikan berdasarkan hasil rata-rata jawaban responden yang terendah pada pernyataan 2 sebesar 3,29, pernyataan 3 sebesar 3,33 dan pernyataan 4 sebesar 3,39 dari hasil jawaban responden.

Analisis regresi linear berganda digunakan untuk memecahkan rumusan masalah yang ada, yaitu untuk melihat pengaruh antara dua variabel atau lebih. Hasil analisis regresi linear berganda dapat dilihat pada Tabel 6 berikut.

Tabel 6.

Hasil Analisis Regresi Linear Berganda

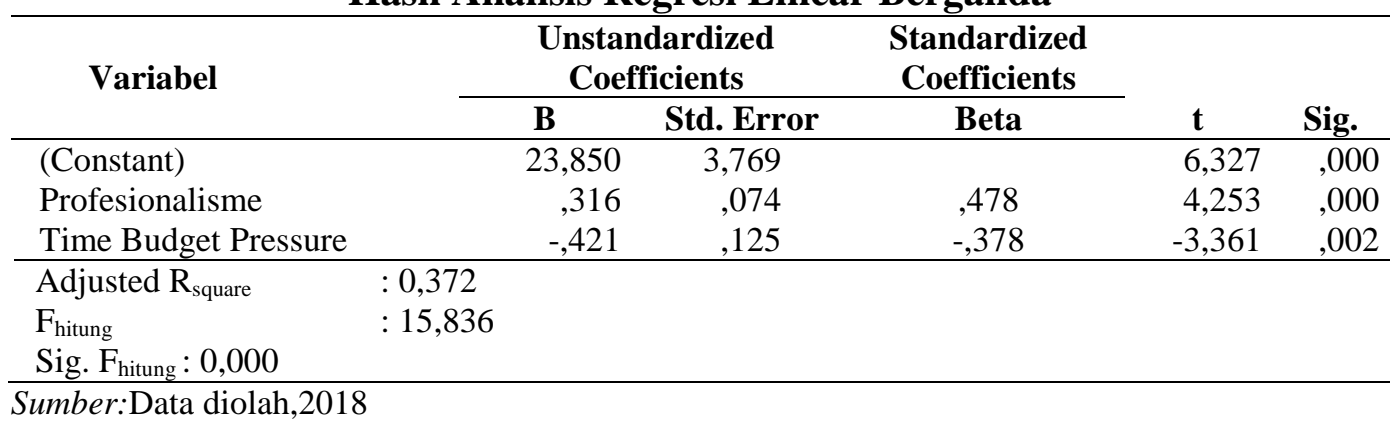

Tabel 6 diatas dapat disusun persamaan regresi untuk menguji pengaruh profesionalisme dan time budget pressure pada kinerja auditor sebagai berikut.

$$
\mathrm{Y}=23,850+0,316 \mathrm{X}_{1}-0,421 \mathrm{X}_{2}
$$

Nilai konstanta $(\alpha)$ sebesar 23,850 menyatakan bahwa jika variabel profesionalisme dan time budget pressure dinyatakan sama dengan konstan pada angka nol, maka nilai kinerja auditor meningkat sebesar 23,850.

Nilai koefisien $\left(\beta_{1}\right)$ sebesar 0,316 menjelaskan apabila variabel profesionalisme mengalami kenaikanmaka kinerja auditor akan mengalami peningkatan. Hal ini berarti semakin besar profesionalisme yang dimiliki, maka kinerja auditor akan semakin meningkat. 
Nilai koefisien $\left(\beta_{2}\right)$ sebesar 0,421 menjelaskan apabila variabel time budget pressure mengalami kenaikanmaka kinerja auditor akan mengalami penurunan. Hal ini berarti semakin tinggi time budget pressure yang dianggarkan maka kinerja auditor akan semakin menurun.

Berdasarkan Tabel 6 dapat dilihat koefisien determinasi yaitu dari nilai adjusted $\mathrm{R}^{2}$ adalah sebesar 0,372 atau $37,2 \%$. Hal ini berarti $37,2 \%$ variasi kinerja auditor dipengaruhi oleh variabel profesionalisme dan time budget pressure, sedangkan 62,8\% dipengaruhi oleh faktor lain di luar model penelitian.

Berdasarkan Tabel 6 menunjukkan bahwa diperoleh nilai $F_{h i t u n g}$ sebesar 15,836 dengan nilai signifikansi $\mathrm{F}$ atau $p$-value sebesar 0,000 yang lebih kecil dari nilai $\alpha=0,05$. Hal ini menunjukkan bahwa model regresi linear berganda layak digunakan sebagai alat analisis untuk menguji pengaruh variabel bebas pada variabel terikat. Hal ini berarti bahwa seluruh variabel bebas (profesionalisme dan time budget pressure) dapat memprediksi atau menjelaskan fenomena kinerja auditor pada Perwakilan BPKP Provinsi Bali.

Berdasarkan hasil pengujian pada Tabel 6 diketahui bahwa $\beta_{1}=0,361$ dengan tingkat signifikansi sebesar 0,000 lebih kecil dari $\alpha=0,05$. Artinya variabel profesionalisme berpengaruh positif dan signifikan pada kinerja auditor. Hasil ini menerima hipotesis pertama $\left(\mathrm{H}_{1}\right)$ yang menyatakan bahwa profesionalisme berpengaruh positif pada kinerja auditor. Semakin tinggi perilaku profesional yang dimiliki auditor, maka akan semakin membentuk karakteristik personal auditor tersebut. Karakteristik personal tersebut merupakan faktor internal yang mendorong seseorang untuk melakukan suatu aktivitas yang 
kemudian akan meningkatkan kinerjanya. Selain itu, semakin tinggi tingkat profesionalisme auditor maka kinerja yang dihasilkan akan semakin memuaskan. Hal ini didukung dari teori atribusi yang menyatakan bahwa individu akan berusaha menganalisis mengapa peristiwa muncul dan hasil dari analisis tersebut akan mempengaruhi perilaku mereka di masa mendatang(Riantiningtyas, 2009).

Hasil penelitian ini selaras dengan hasil penelitian yang dilakukan oleh Prabhawa(2014) menyatakan auditor yang bersikap profesional lebih dipercaya sebagai seorang auditor yang memiliki kompetensi yang baik sehingga hasil audit yang diberikan akan semakin baik. Berdasarkan hal tersebut, maka dapat digambarkan jika seorang auditor pemerintah yang memiliki profesionalisme dengan baik akan bekerja secara profesional yang nantinya akan dapat meningkatkan kinerja auditor di Perwakilan BPKP Provinsi Bali.

Berdasarkan hasil pengujian pada Tabel 6 diketahui bahwa $\beta_{2}=-0,421$ dengan tingkat signifikansi sebesar 0,002 lebih kecil dari $\alpha=0,05$. Artinya variabel time budget pressure berpengaruh negatif dan signifikan pada kinerja auditor. Hasil ini menerima hipotesis kedua $\left(\mathrm{H}_{2}\right)$ yang menyatakan bahwa time budget pressure berpengaruh negatif pada kinerja auditor. Teori atribusi menyatakan bahwa atribusi eksternal dapat mempengaruhi perilaku seseorang. Hal ini memberikan penjelasan bahwa faktor eksternal seperti tekanan anggaran waktu auditor bisa saja mengubah perilaku auditor. Adanya tekanan individual dari seorang auditor akibat adanya anggaran waktu yang semakin ketat sehingga dapat menurunkan kualitas audit yang dihasilkan. Semakin tinggi tekanan 
Made Irna Wikanadi dan Ketut Alit Suardana. Pengaruh...

anggaran waktu yang diberikan maka kinerja dari seorang auditor akan semakin menurun.

Berdasarkan hal tersebut, dapat digambarkan bahwa time budget pressure memiliki peran dalam menentukan kinerja auditor yang dihasilkan oleh auditor diPerwakilan BPKP Provinsi Bali. Temuan ini sejalan dengan penelitian yang dilakukan oleh Prasita dan Adi (2007), Hutabarat(2012), sertaNingsih(2013) yang menyatakan bahwa terdapat pengaruh yang negatif antara time budget pressure yang diberikan terhadap kinerja auditor. Adanya tekanan anggaran waktu yang tinggi dapat menurunkan kualitas dari kinerja seorang auditor di Perwakilan BPKP Provinsi Bali.

Berdasarkan hasil olah data dengan bantuan SPSS, maka didapatkan hasil analisis regresi moderasi yang dapat dilihat pada Tabel 8 berikut.

\section{Tabel 7.}

Hasil Analisis Regresi Moderasi

\begin{tabular}{|c|c|c|c|c|c|}
\hline \multirow[t]{2}{*}{ Variabel } & \multicolumn{2}{|c|}{$\begin{array}{l}\text { Unstandardized } \\
\text { Coefficients }\end{array}$} & \multirow{2}{*}{$\begin{array}{c}\text { Standardized } \\
\text { Coefficients } \\
\text { Beta } \\
\end{array}$} & \multirow[b]{2}{*}{$\mathbf{t}$} & \multirow[b]{2}{*}{ Sig. } \\
\hline & B & Std. Error & & & \\
\hline (Constant) & 133,799 & 20,394 & & 6,561 &, 000 \\
\hline Profesionalisme & $-1,437$ &, 429 & $-2,174$ & $-3,349$ & 002 \\
\hline Time Budget Pressure & $-2,559$ & ,734 & $-2,294$ & $-3,486$ & 001 \\
\hline Motivasi Auditor & $-3,878$ & ,713 & $-3,912$ & $-5,439$ & ,000 \\
\hline Interaksi $\mathrm{X}_{1}$ dan $\mathrm{M}$ & 062 & 015 & 3,146 & 4,099 & 000 \\
\hline Interaksi $\mathrm{X}_{2}$ dan $\mathrm{M}$ &, 076 &, 026 & 2,537 & 2,956 &, 005 \\
\hline Adjusted $\mathrm{R}_{\text {square }}$ & $: 0,611$ & & & & \\
\hline$F_{\text {hitung }}$ & $: 16,712$ & & & & \\
\hline Sig. $F_{\text {hitung }}: 0,000$ & & & & & \\
\hline
\end{tabular}

Tabel 7 diatas dapat disusun persamaan regresi untuk menguji pengaruh profesionalisme dan time budget pressure pada kinerja auditor dengan motivasi auditor sebagai variabel pemoderasi sebagai berikut.

$$
\mathrm{Y}=133,799-1,437 \mathrm{X}_{1}-2,559 \mathrm{X}_{2}-3,878 \mathrm{M}+0,062 \mathrm{X}_{1} \mathrm{M}+0,076 \mathrm{X}_{2} \mathrm{M}
$$


Nilai konstanta $(\alpha)$ sebesar 133,799 menyatakan bahwa jika variabel profesionalisme, time budget pressure dan motivasi auditor dinyatakan sama dengan konstan pada angka nol, maka nilai kinerja auditor meningkat sebesar $133,799$.

Nilai koefisien $\left(\beta_{1}\right)$ variabel profesionalisme memiliki koefisien bernilai negatif.Nilai koefisien ini menjelaskan bahwa setiap kenaikanvariabel profesionalisme maka kinerja auditor akan mengalami penurunan dengan asumsi nilai variabel independen lainnya konstan (tidak berubah).

Nilai koefisien $\left(\beta_{2}\right)$ variabel time budget pressurememiliki koefisien bernilai negatif.Nilai koefisien ini menjelaskan bahwa setiap kenaikanvariabel time budget pressure maka kinerja auditor akan mengalami penurunan dengan asumsi nilai variabel independen lainnya konstan (tidak berubah).

Nilai koefisien $\left(\beta_{3}\right)$ variabel motivasi auditor memiliki koefisien bernilai negatif.Nilai koefisien ini menjelaskan bahwa setiap kenaikanvariabel motivasi auditor maka kinerja auditor akan mengalami penurunan dengan asumsi nilai variabel independen lainnya konstan (tidak berubah).

Nilai koefisien $\left(\beta_{4}\right)$ interaksi variabel profesionalisme dan motivasi auditor memiliki pengaruh positif pada kinerja auditor. Hal ini mengindikasikan bahwa efek moderasi yang diberikan adalah positif, artinya semakin tinggi moderasi motivasi auditor maka pengaruh profesionalisme pada kinerja auditor semakin meningkat.

Nilai koefisien $\left(\beta_{5}\right)$ interaksi variabel time budget pressure dan motivasi auditor memiliki pengaruh positif pada kinerja auditor. Hal ini mengindikasikan 
bahwa efek moderasi yang diberikan adalah positif, artinya semakin tinggi moderasi motivasi auditor maka pengaruh time budget pressure pada kinerja auditor semakin meningkat.

Berdasarkan Tabel 7 dapat dilihat koefisien determinasi yaitu dari nilai adjusted $\mathrm{R}^{2}$ adalah sebesar 0,611 atau $61,1 \%$. Hal ini berarti $61,1 \%$ variasi kinerja auditor dipengaruhi oleh variabel profesionalisme, time budget pressure dan motivasi auditor, sedangkan 38,9\% dipengaruhi oleh faktor lain di luar model penelitian.

Berdasarkan Tabel 7 menunjukkan bahwa diperoleh nilai $F_{\text {hitung }}$ sebesar 16,712 dengan nilai signifikansi $\mathrm{F}$ atau $p$-value sebesar 0,000 yang lebih kecil dari nilai $\alpha=0,05$. Hal ini menunjukkan bahwa model regresi moderasi layak digunakan sebagai alat analisis untuk menguji pengaruh variabel bebas pada variabel terikat. Hal ini berarti bahwa seluruh variabel bebas (profesionalisme, time budget pressure dan motivasi auditor) dapat memprediksi atau menjelaskan fenomena kinerja auditor pada Perwakilan BPKP Provinsi Bali.

Berdasarkan hasil pengujian pada Tabel 7 diketahui bahwa $\beta_{4}=0,062$ dengan tingkat signifikansi sebesar 0,000 lebih kecil dari $\alpha=0,05$. Artinya variabel motivasi auditor mampu memoderasi pengaruh profesionalisme pada kinerja auditor. Hasil ini menerima hipotesis ketiga $\left(\mathrm{H}_{3}\right)$ yang menyatakan bahwa motivasi auditor meningkatkan pengaruh profesionalisme pada kinerja auditor. Berdasarkan teori atribusi, faktor internal dan eksternal motivasi dalam diri dan luar auditor membawa pengaruh positif atau peningkatan terhadap 
profesionalisme yang lebih baik sehingga meningkatkan kinerja auditor dalam melaporkan hasil auditnya.

Hasil penelitian ini selaras dengan hasil penelitian dari Siregar(2014) yang menyatakan bahwa seorang auditor dapat bekerja sama dan berkinerja dengan baik, maka seorang auditor harus mempunyai profesionalisme dalam menerapkan suatu profesi yang dimiliki dan menjadi suatu motivasi kerja untuk meningkatkan hasil kinerja auditor yang diharapkan.

Berdasarkan hasil pengujian pada Tabel 7 diketahui bahwa $\beta_{5}=0,076$ dengan tingkat signifikansi sebesar 0,005 lebih kecil dari $\alpha=0,05$. Artinya variabel motivasi auditor mampu memoderasi pengaruh time budget pressure pada kinerja auditor. Hasil ini menerima hipotesis keempat $\left(\mathrm{H}_{4}\right)$ yang menyatakan bahwa motivasi auditor meningkatkan pengaruh time budget pressure pada kinerja auditor. Menurut Kurnia dkk., (2014) atibusi eksternal dinyatakan dapat mempengaruhi evaluasi kinerja individu. Berdasarkan hal tersebut diperoleh penjelasan bahwa atribusi eksternal tekanan anggaran waktu audit dapat mempengaruhi kinerja individu. Atribusi ekstenal ini mempengaruhi perilaku auditor melalui tekanan yang dirasakan auditor sebagai akibat dari susunan anggaran waktu audit yang dialami ketika melaksanakan penugasan audit.

Melihat hasil regresi time budget pressure berpengaruh negatif terhadap kinerja auditor, tetapi disisi lain adanya pengaruh positif yang dapat ditimbulkan dari tekanan anggaran waktu salah satunya adalah muncul motivasi yang tinggi dari seorang auditor untuk dapat menyelesaikan pekerjaannya tepat pada waktu yang telah dianggarkan.Hal ini selaras dengan hasil penelitian yang dilakukan 
oleh Rustiarini(2013)yang menyatakan bahwa adanya respon yang positif dalam menghadapi tekanan waktu yang tinggi, sehingga digunakan sebagai alat untuk memotivasi auditor dalam meningkatkan kualitas pekerjaannya.

\section{SIMPULAN}

Profesionalisme berpengaruh positif pada kinerja auditor di Perwakilan BPKP Provinsi Bali. Hal ini bermakna bahwa semakin tinggi tingkat profesionalisme auditor maka kinerja yang dihasilkan akan semakin memuaskan.

Time budget pressure berpengaruh negatif pada kinerja auditor di Perwakilan BPKP Provinsi Bali. Hal ini bermakna bahwa semakin tinggi tekanan anggaran waktu yang diberikan maka kinerja dari seorang auditor akan semakin menurun.

Motivasi auditor meningkatkan pengaruh profesionalisme pada kinerja auditor. Hal ini bermakna semakin tinggi tingkat profesionalisme auditor maka kinerja yang dihasilkan akan semakin memuaskan, dengan adanya motivasi auditor maka dapat meningkatkan pengaruh profesionalime pada kinerja auditor.

Motivasi auditor meningkatkan pengaruh time budget pressure pada kinerja auditor. Hal ini bermakna bahwa semakin tinggi tekanan anggaran waktu yang diberikan maka kinerja dari seorang auditor akan semakin menurun, dengan adanya motivasi auditor maka dapat meningkatkan pengaruh time budget pressure pada kinerja auditor.

Penelitian ini diharapkan dapat memberikan gambaran bagi Perwakilan BPKP Provinsi Bali untuk dapat membuat kesepakatan mengenai tekanan 
anggaran waktu yang dianggarkan untuk setiap penugasan agar tidak terlalu ketat, karena semakin tinggi tekanan anggaran waktu yang dibuat akan menyebabkan auditor kurang mampu memenuhi target yang telah ditentukan sehingga dapat menurunkan kualitas kinerja dari seorang auditor. Selain itu, sebaiknya Perwakilan BPKP Provinsi Bali menciptakan lingkungan kerja yang menyenangkan untuk dapat membuat auditor nyaman dalam bekerja agar motivasi yang ada dalam diri seorang auditor semakin meningkat maka kinerja yang dihasilkan menjadi lebih baik.

Penelitian ini diharapkan dapat memberikan gambaran bagi auditor di Perwakilan BPKP Provinsi Bali bahwa dengan adanya profesionalisme dalam diri seorang auditor pada penugasan yang diberikan selama bekerja maka akan memberikan motivasi bagi auditor untuk bekerja lebih giat lagi dan sebaiknya auditor di Perwakilan BPKP Provinsi Bali tetap mencari ilmu yang berkaitan dengan profesinya untuk dapat diterapkan di BPKP baik dibidang internal kontrol, penguatan internal audit maupun simda sebagai upaya menjaga kualitas kinerjanya dalam penugasan audit.

Hasil penelitian ini diharapkan dapat memberikan kontribusi dan tambahan pengetahuan dalam pengembangan teori-teori yang sesuai dengan penelitian yang dilakukan. Berdasarkan hasil adjusted $\mathrm{R}$ square dengan regresi linear berganda yang menunjukkan jumlah sebesar 0,372 atau $37,2 \%$ variasi pada kinerja auditor dipengaruhi oleh variabel profesionalisme dan time budget pressure. Sementara sisanya $62,8 \%$ diharapkan penelitian selanjutnya dapat menambahkan variabel lain yang dapat berpengaruh pada kinerja auditor. Berdasarkan hasil adjusted $\mathrm{R}$ 
square dengan regresi moderasi yang menunjukkan jumlah sebesar 0,611 atau 61,1\% variasi pada kinerja auditor dipengaruhi oleh variabel profesionalisme, time budget pressure, dan motivasi auditor. Sementara sisanya 38,9\% variasi pada variabel kinerja auditor dipengaruhi oleh variabel lain yang tidak diteliti dalam penelitian ini. Bagi peneliti selanjutnya yang tertarik untuk melakukan penelitian sejenis, disarankan untuk meneliti dengan menggunakan variabel yang berbeda yang dapat berpengaruh pada kinerja auditor.

\section{REFERENSI}

Ahituv, Niv and Magid, I. (1998). The Effect of Time Budget Pressure and Completeness of Information on Decision Making. Journal Management Information System, 15(2), 153-172.

Alderman, C.W., and Deitrick, J. (1982). Auditor's Perception of Time Budget Pressure and Premature Sign-Off. A Journal of Practice and Theory (Winter).

Arisinta, Octaviana. (2013). Pengaruh Kompetensi, Independensi, Time Budget Pressure dan Audit Fee Terhadap Kualitas Audit Pada Kantor Akuntan Publik di Surabaya. Jurnal. Fakultas Ekonomi Dan Bisnis Universitas Airlangga, (3), 266-278.

Asri Usman, Made Sudarma, Hamid Habbe, and Darwis Said. (2014). Effect of Competence Factor, Independence and Attitude against Professional Auditor Audit Quality Improve Performance in Inspectorate (Inspectorate Empirical Study in South Sulawesi Province). Journal of Business and Management, 16(1), 1-13.

Baotham, S. (2007). Effects of Professionalism on Audit Quality and Self-image of CPAs in Thailand. International Journal of Business Strategy. Thailand, $7(2)$.

Cahyani, Purnamawati. dan Herawati. (2015). Pengaruh Etika Profesi Auditor, Profesionalisme, Motivasi, Budaya Kerja dan Tingkat Pendidikan terhadap Kinerja Auditor di Kantor Akuntan Publik. E-Journal S1 Ak Universitas Pendidikan Ganesha. 
Christiyanto, Dedy (2011). Pengaruh Kemampuan, Motivasi dan Pengalaman terhadap Kinerja Auditor Independen. Jurnal Jurusan Akuntansi Fakultas Ekonomi Dan Bisnis Universitas Brawijaya.

Cook, E., and Kelly, T. (1991). An International Comparison of Audit TimeBudget Pressures. The Woman CPA Journal, 53, 25-30.

Coram, P., Ng, J., and Woodliff, D. (2003). A Survey of Time Budget Pressure and Reduced Audit Quality among Australian Auditors. Australian Accounting Review, 13(1), 38-45.

DeZoort, F.T., and Lord, A. . (1997). A Review and Synthesisof Pressure Effects Research in Accounting. Journal of Accounting Literature, 16, 28-86.

Handayani, Rikha dan Yusrawati. (2012). Pengaruh Profesionalisme, Komitmen Organisasi dan Budaya Kerja terhadap Kinerja Internal Auditor pada Bank Mandiri Medan. Jurnal Ekonomi Manajemen Dan Akuntansi, 21(2).

Haris, Fuad. (2015). Pengaruh Pengalaman, Otonomi, Profesionalisme, Ambiguitas Peran, dan Motivasi terhadap Kinerja Auditor. Skripsi. Universitas Muhammadiyah Surakarta.

Hudiwinarsih, Gunasti. (2010). Auditors' Experience, Competency, And Their Independency of Internal Auditors. Electronic Journal of Business Ethics and Organization Studies, 15(1).

Hutabarat, Goodman. (2012). Pengaruh Pengalaman Time Budget Pressure dan Etika Auditor terhadap Kualitas Audit. Jurnal Akuntansi Fakultas Ekonomi. Universitas Satya Negara Indonesia.

Indrajaya, AA Ngurah., Astika, Ida Bagus Putra., dan Ni Putu Sri Harta Mimba. (2017). Pengaruh Intellegence Quotient, Emotional Quotient, Spiritual Quotient, dan Time Budget Pressure pada Perilaku Underreporting of Time. Jurnal Ilmiah Akuntansi Dan Bisnis, 12(2), 82-92.

Kalbers, L. P., and Fogarty, T. J. (1995). Professionalism and Its Consequences: A Study of Internal Auditors. A Journal of Practice and Theory.

Kelley, T. . and R. E. Seiler. (1982). Auditor Stress and Time Budgets. The CPA Journal.

Khadilah, Risma., Pupung Purnamasari., dan Hendra Gunawan. (2015). Pengaruh Time Budget Pressure, Pengalaman Auditor, Etika Auditor, dan Kompleksitas Audit terhadap Kualitas Audit. Prosiding Penelitian SPeSIA. 
Kurnia., Khomsiyah., dan Sofie. (2014). Pengaruh Kompetensi, Independensi, Tekanan Waktu, dan Etika Auditor Terhadap Kualitas Audit. E-Journal Akuntansi Fakultas Ekonomi Universitas Trisakti, (1), 49-67.

Kusnadi, I Made Gheby. (2015). Pengaruh Profesionalisme dan Locus Of Control terhadap Kinerja Auditor di Kantor Akuntan Publik Provinsi Bali. E-Jurnal Akuntansi Universitas Udayana, 13(1), 276-291.

Lautania, Maya Febrianty. (2011). Pengaruh Time Budget Pressure, Locus of Control dan Perilaku Disfungsional Audit terhadap Kinerja Auditor (Studi pada Kantor Akuntan Publik Indonesia). Jurnal Telaah Dan Riset Akuntansi. Fakultas Ekonomi Universitas Syiah Kuala, 4(1), 92-113.

Liyanarachchi, Gregory A., and McNamara, Shaun M. (2007). Time Budget Pressure in New Zealand Audits. Business Review, 9(2), 61-68.

Marganingsih dan Martani. (2002). Analisis Variabel Anteseden Perilaku Auditor Internal dan Konsekuensinya terhadap Kinerja: Studi Empiris pada Auditor di Lingkungan Aparat Pengawasan Intern Pemerintah-Lembaga Pemerintah Non Departemen. Jurnal Riset Akuntansi Indonesia, 5(3).

Marion, Hutchinson. (2009). Internal Audit Quality, Audit Committee Independence, Growth Opportunities and Firm Performance. International Journal of Business and Social Science, 7(2), 50-63.

Mcdaniel, Linda. S. (1990). The Effects of Time Pressure and Audit Program Structure on Audit Performance. Journal of Accounting Research, 28(2), 267-285.

Mu'azu Saidu Badara and Siti Zabedah Saidin. (2013). The Relationship between Audit Experience and Internal Audit Effectiveness in the Public Sector Organizations. International Journal of Academic Research in Accounting, Finance and Management Sciences, 3(3), 329-339.

Ningsih, A. A. Putu Ratih Cahaya. (2013). Pengaruh Kompetensi, Independensi, dan Time Budget Pressure terhadap Kualitas Audit. E-Jurnal Akuntansi Universitas Udayana, 4(1), 92-109.

Peraturan Presiden Nomor 192 Tahun 2014 Badan Pengawasan Keuangan dan Pembangunan. 31 Desember 2014. Lembaran Negara Republik Indonesia Tahun 2014 Nomor 400. Jakarta.

Prabhawa, Ketut Ardy. (2014). Pengaruh Supervisi, Provesionalisme, dan Komunikasi dalam Tim pada Kinerja Auditor Perwakilan BPKP Provinsi Bali. E-Journal. Universitas Pendidikan Ganesha Jurusan Akuntansi Program S1, 2(1). 
Prasita, A., dan Adi, P. H. (2007). Pengaruh Kompelsitas Tugas dan Tekanan Anggaran Waktu Terhadap Kualitas Audit dengan Moderasi Pemahaman Terhadap Sistem Informasi. Jurnal Ekonomi Dan Bisnis Fakultas Ekonomi. UKSW, 1-24.

Putri, Kompiang K.M. Dinata dan Suputra, I. D.G Dharma. (2013). Pengaruh Independensi, Profesionalisme dan Etika Profesi Terhadap Kinerja Auditor pada Kantor Akuntan Publik di Bali. E-Jurnal Akuntansi Universitas Udayana.

Ramadika, A,P., Nasir, A., dan Wiguna, M. (2014). Pengaruh Role Stress, Gender, Struktur Audit dan Profesionalisme terhadap Kinerja Auditor BPKRI Perwakilan Provinsi Riau. Jurnal Online Mahasiswa (JOM) Bidang Ilmu Ekonomi, 1(2), 1-15.

Riantiningtyas, A. (2009). Pengaruh Role Stressors dan Self Esteem terhadap Timbulnya Burnout dan Konsekuensinya terhadap Job Outcomes Auditor di Indonesia. Ejournal Universitas Diponegoro.

Rustiarini, Ni Wayan. (2013). Sifat Keperibadian dan Locus of control sebagai Pemoderasi Hubungan Stress Kerja dan Perilaku Disfungsional Audit. Simposium Nasional Akuntansi XVI.

Siregar, Alex Dwiputra. (2014). Pengaruh Profesionalisme dan Locus Of Control Terhadap Prestasi Kerja Auditor: Motivasi Kerja Sebagai Variabel Intervening. Skripsi. STIE Perbanas Surabaya.

Sujana, Edy. (2012). Pengaruh Kompetensi, Motivasi, Kesesuaian Peran dan Komitmen Organisasi Terhadap Kinerja Auditor Internal Inspektorat Pemerintahan Kabupaten (Studi Pada Kantor Inspektorat Kabupaten Badung dan Buleleng). E-Journal S1 Ak Universitas Pendidikan Ganesha.

Sukendro, Doso. (2015). Laporan Pemberian Keterangan Ahli pada perkara dugaan tindak pidana korupsi Pengadaan Barang dan jasa, Tahun 2012pada IHDN Denpasar, Denpasar, BPKP.

Sumardi dan Hardiningsih. (2002). Pengaruh Pengalaman terhadap Profesionalisme serta Pengaruh Profesionalisme terhadap Kinerja dan Kepuasan Kerja: Studi Kasus Auditor BPKP Semarang. Jurnal Bisnis Dan Ekonomi.

Trisnaningsih, Sri. (2007). Independensi Auditor dan Komitmen Organisasi Sebagai mediasi Pengaruh Pemahaman Good Governance, Gaya Kepemimpinan dan Budaya Organisasi Terhadap Kinerja Auditor. Simposium Akuntansi Nasional X, 26 - 28 Juli 2007. 
Made Irna Wikanadi dan Ketut Alit Suardana. Pengaruh...

Willett, C., and Page, M. (1996). A Survey of Time Budget Pressure and Irregular Auditing Practices Among Newly Qualified UK Chartered Accountants. The British Accounting Review, 28(2), 101-120. 